\title{
TEACHING FACTORS THAT AFFECT STUDENTS' LEARNING MOTIVATION: BANGLADESHI EFL STUDENTS' PERCEPTIONS
}

\author{
Moriam Quadir \\ (moriam@ewubd.edu) \\ East West University \\ Aftab Nagar, Rampura, Dhaka, Bangladesh 1212
}

\begin{abstract}
Research literature consistently suggests that EFL (English as a foreign language) students' motivation is affected by some teaching factors (Falout et al., 2009; Kim et al., 2018; Lamb, 2017). The main purpose of this study is to identify exactly which teaching factors adversely affect students' motivation to study English at higher secondary (HS) level (grade 11 and 12) in Bangladeshi EFL context. To collect qualitative data an interview protocol was developed based on the teaching factors identified in some selected studies conducted in Asian EFL contexts (Kikuchi, 2009; Sakai \& Kikuchi, 2009; Trang \& Baldauf, 2007; Quadir, 2017). A total number of 40 grade 12 completers were interviewed to collect students' perceptions. Miles and Huberman's (1994) qualitative data analysis procedure was applied to analyze the data. From the analysis five distinct factors, which adversely affect students' motivation, are identified in descending order: teachers' instructional styles and teaching method, private tutoring, teachers' personality and behavior, teachers' competence and classroom management, and teachers' attitude and commitment. Most of these factors comprise further subcomponents which detect the underlying sources of students' disinterest. For amelioration of the situations some feasible implications are discussed addressing the identified factors.
\end{abstract}

Keywords: Bangladesh, EFL context, English teachers, students' de/motivation, students' perceptions

DOI: http://dx.doi.org/10.15639/teflinjournal.v32i2/295-315

Across wide EFL (English as a foreign language) contexts research studies quite consistently indicate that some teaching practices construct the most potent factors that adversely affect students' motivation to study English as a school subject (Falout et al., 2009; Kim et al., 2018; Lamb, 2017; Quadir, 2017). In 
classroom environments students engage in learning activities under the instructional guidance of their English teachers. The repeated emergence of the teacher-related demotivation factors in the EFL studies necessitates individual research investigations into the issue in different contexts to identify the underlying factors and to work out contextually realistic remedial measures to ameliorate the situations.

The study reported in this article took place in Bangladeshi context. Since English language learning is mostly confined to classroom usages, Bangladesh is seen as an EFL context in this study. Bangladesh has one of the largest EFL high school student populations in the world (Hamid \& Honan, 2012). English education is emphasized across all academic levels in the state. In the mainstream of state education system, English is taught as a compulsory school subject from grade 1 to grade 12. At higher secondary (HS) level (grade 11 and 12) two English papers are taught for $3 / 4$ hours per-week in institutional settings. In all institutional and public examinations English papers are held in high regard by the stakeholders (Hamid et al., 2017). However, every year massive failures are reported in English papers in the public examinations under the national curriculum (Hamid et al., 2017).

In the current society of Bangladesh, English language proficiency is highly regarded as a "crucial linguistic capital" (Hamid et al., 2017, p. 870) which is associated with higher education, job opportunities, immigration, and many other future prospects (Hamid et al., 2017). Both in rural and urban regions, proficiency in English is regarded as a means of social and economic achievements across social classes (Erling et al., 2014). Both students and their parents are acutely aware of the instrumental values of English for their future achievements. English occupies students' "thoughts and consciousness, more than any other school subjects" (Hamid \& Baldauf, 2011, p. 201).

English language education in Bangladesh was traditionally based on grammar translation method. However, a major shift took place in 2001 in the process of revising the conventional English curriculum into CLT (Communicative Language Teaching) based curriculum with the aim of enhancing human resources development efforts of the government of Bangladesh (NCTB, 2003). Although the curriculum was revised with the objective of achieving the outcomes of communicative-competence-based teaching-learning approaches, in reality, almost the same traditional practices persist in classrooms (Rahman \& Pandian, 2018). 
In Bangladeshi English language classrooms, the conventional teachercentered pedagogy is mostly practiced. A formal and remote relationship (Rahman \& Pandian, 2018) is maintained between teachers and students. Teachers commonly believe that they must hold "the supreme command" on the class (Rahman et. al., 2019, p. 600). The medium of instruction is mostly L1 (Bangla) in English language classrooms. Teachers practically lack quality materials and logistic support for conducting classroom activities. Both quality and quantity of classroom activities are questioned by a number of researchers (Alam, 2018; Rahman et. al., 2019). The widely perceived uselessness of classroom instructions compels a large number of students to buy private tuition in English in many different forms investing huge amount of money in the lowincome country (Hamid et al., 2017; Quadir, 2017). In the peripheral rural areas, the quality of classroom instruction is evidently poorer compared to the urban schools.

The shortage of qualified, competent and English-proficient teachers is a commonly cited barrier to achieving the expected outcomes of English education in Bangladesh (Alam, 2018; Hamid et al., 2017; Rahman et al., 2018). The conventional parameters of assessing teachers' quality are education, experience, and professional support (Stockwell, 2015). But regrettably, most of the components are lacking in the current English language education system in Bangladesh. The existing teachers' training capacity for English language teachers is inadequate and ineffective (Karim et al., 2018). It is important to note that the English teachers in Bangladesh have never been provided with adequate logistic facilities, nor even effective guidance, or teaching materials to cope with the curriculum requirements (Islam, 2015). The resulted gaps lead high school English teachers to follow their individualized, used to, and to some extent incompatible approaches in teaching English in classrooms (Ali \& Walker, 2014). In other words, inadequate provision of pedagogical guidance and teaching-learning materials leads English teachers to confine their teaching practices within their familiar and preferred instructional approaches ignoring curricular requirements.

High school (HS) students in Bangladesh learn English as a school subject amid all these contextual constrains of classroom teaching. The conventional teaching practices conducted in HS level classrooms may affect students' inherent motivation to study English to gain proficiency with the objective to secure a better future. Therefore, it is necessary to take students' perceptions and 
experiences of their classroom teaching-learning practices into account to identify the teaching factors that adversely affect their motivation to study English.

\section{Studies Conducted in EFL Contexts}

A large body of research conducted in a wide range of EFL contexts reveals that the top-ranking attributions of students' demotivation to study English are consistently teaching factors. In other words, EFL learners quite repeatedly and invariably attribute their disinterest towards learning English to the teaching practices in their English classrooms (Falout et al., 2009). Instructors' disagreeable behaviors and personalities, instructional styles and teaching methods, poor linguistic competence are the most commonly cited reasons of students' losing motivation to study English as a school subject. These factors of students' demotivation recurrently appear in a number of studies conducted across many Asian EFL contexts.

Presumably the highest numbers of EFL demotivation research investigations are conducted in Japanese context. Kikuchi (2009) collected data from 656 Japanese high school students in a quantitative study and identified teachers' behavior and teaching methods as the major sources of learners' demotivation to study English. In the same context, Sakai and Kikuchi (2009) detected teachers' competence and teaching style as the second dominant factor which adversely affects students' motivation to study English. Falout et al. (2009) in a large-scale research investigation on 900 Japanese university EFL students identified that teacher immediacy was the most influential external factor which negatively affects learners' motivation.

In Korean EFL context, a good number of research works have been conducted to explore students' de/motivation factors. Jung (2011) collected data from HS students by administering reflective questionnaire. The study listed boring lectures, ways of teaching grammar and vocabulary as the teaching factors that demotivate students to learn English. In a qualitative research study based on autobiographic essays, Kim and Lee (2013) identified that teaching practices construct the most dominant factors which negatively affect EFL learners' motivation. Song and Kim (2017) conducted a study by administering open-ended questionnaire to identify high school EFL students' demotivation factors. They found that teaching factors like teacher-centered pedagogy, examfocused teaching, insufficient opportunity for participation in classroom 
activities, and persuasion for memorization demotivate HS students towards learning English. Kim et al. (2018) conducted a qualitative inquiry on Korean young EFL learners and found that teachers' incomprehensible explanation was one of the potent factors which adversely affect learners' motivation.

In a research study conducted in Vietnamese EFL context, Trang and Baldauf (2007) identified external and internal demotivation factors by analyzing stimulated recall essays of university students. They detected teacherrelated factors as the strongest external attributions which negatively affect students' motivation in that context. Under this factor the specific sources of learners' demotivation were teaching method, teachers' behavior, teachers' competence, grading and assessment.

Alavinia and Sehat (2012) conducted a study in Iranian EFL context to identify the factors affecting students' motivation to learn English. They collected data from HS students using questionnaire. Through quantitative analysis they found that teachers 'personality and behavior were the most salient factors which adversely affect EFL learners' motivation. In the same EFL context, Heidari and Oghli (2015) distributed questionnaire among HS students. The study detected teacher-related factors as the strongest demotivators to learn English.

\section{Research Conducted in Bangladesh}

Turning to the research conducted in Bangladeshi education context, it appears that impacts of teaching factors on EFL learner motivation have not yet received any notable research attention. Quadir (2017) conducted qualitative research to investigate the general sources of HS students' demotivation to study English as a school subject in the educational context of Bangladesh. In the study, English teachers was identified as the most dominant factor which affects students' motivation to study English as compulsory school subject. Under this potent factor some underlying themes were detected: teachers' instructional style, personality, attitude, and competence.

In the history of EFL research in Bangladesh, students' perceptions of classroom teaching practices are rarely explored. It is necessary to listen to their experiences and feelings as they learn English sitting in the classrooms staying in close contact with their instructors. This current study emphasizes learnercenteredness in methodology since the first-hand information is essential to capture a critical and in-depth understanding of a phenomenon in an educational 
context (Creswell \& Poth, 2017). In the area of L2 education, researchers (see Benson, 2005; Hamid \& Baldauf, 2011) have emphasized the necessity of learner-centered study focusing on students' language learning experiences explained from their point of views. To develop effective learning environment in an EFL context, researching students' experiences and perceptions from their perspectives is essential. The main objective of this study is to explore HS students' perceptions regarding the teaching factors which negatively affect their motivation to study English.

\section{METHOD}

\section{Participants}

The current study used a convenience sample consisting of 40 grade 12 completers of four different institutions. The participants completed their HSC (Higher Secondary Certificate) examination within the previous 1 to 4 months at the time of data collection. Since they had recently completed their HS level, they were considered to be articulate to report their perceptions and experiences regarding the teaching practices that adversely affect their learning motivation to study English. All the participants were students of the mainstream national curriculum. Their age ranged from 18 to 19. Among the participants 17 were females and 23 were males. Of them $42 \%$ participants completed their HS education from urban schools, $25 \%$ from sub-urban schools, and the rest (33\%) were from rural schools. As it was possible to manage access to HS completers of diverse local contexts through convenient sampling procedure by contacting institutional members, 40 participants from four institutions were considered to be adequate for the current study.

\section{Data Collection and Analysis}

To collect qualitative data for the study an interview guide was designed based on the recurring teaching factors identified in some selected studies (Kikuchi, 2009; Quadir, 2017; Sakai \& Kikuchi, 2009; Trang \& Baldauf, 2007) on EFL students' de/motivation conducted in some Asian EFL contexts. Analyzing the list of the factors, the researcher incorporated the following items in the interview guide: English teachers' instructional skills, teaching methods, attitude towards students, behaviors, classroom management skills, commitment to teaching, and attitude towards private tutoring. At the end of each interview 
the participant was asked to add perceptions which were not listed in the protocol. The interviews were conducted in their L1, Bangla. An English version of the interview protocol is put in the Appendix. The first two questions were asked to create an ice-breaking effect. All the participants were interested and willing to share their perceptions. The participants were informed about the purpose and content of the interview one to two days earlier to give them time to recollect the relevant experiences and perceptions regarding the teaching practices of their recently completed academic level. The one-to-one interviews took 40 to 50 minutes time. Their reported perceptions were audio recorded. The recordings were transcribed verbatim by the researcher, and accuracy was checked by a colleague.

In order to identify the factors, the collected data were analyzed following the qualitative data analysis procedure suggested by Miles and Huberman (1994). They suggested a three-step procedure for qualitative data analysis: data reduction, data display, conclusion drawing and verification. The qualitative data collected from the interviews were reduced and displayed by constructing matrices.

\section{FINDINGS AND DISCUSSION}

\section{Factors that Adversely Affect Students' Motivation}

Of the total number of 40 participants, 34 (85\%) reported that some aspects of their English teachers' teaching practices adversely affected their motivation to study English at HS level. The rest of them (15\%) did not report any negative influence of their institutional English teaching on their learning motivation. Based on the constructed matrices of learners' account, five distinct factors that negatively affect students' motivation are identified. At least $70 \%$ participants cited the points under the constructed factors. All the five factors are listed in Table 1 in order of the most to least reported.

Table 1. Teaching Factors which Affect Students' Motivation

\begin{tabular}{|l|l|c|c|}
\hline \multicolumn{2}{|l|}{ Factors } & $\begin{array}{c}\text { Number of participants } \\
\text { mentioning the point }\end{array}$ & $\begin{array}{c}\text { Percentage of } \\
\text { mentions }\end{array}$ \\
\hline Factor 1 & $\begin{array}{l}\text { Instructional styles and } \\
\text { teaching method }\end{array}$ & 32 & $80 \%$ \\
\hline Factor 2 & Private tutoring & 30 & $75 \%$ \\
\hline
\end{tabular}


302 TEFLIN Journal, Volume 32, Number 2, July 2021

\begin{tabular}{|l|l|c|c|}
\hline \multicolumn{2}{|l|}{ Factors } & $\begin{array}{c}\text { Number of participants } \\
\text { mentioning the point }\end{array}$ & $\begin{array}{c}\text { Percentage of } \\
\text { mentions }\end{array}$ \\
\hline Factor 3 & $\begin{array}{l}\text { Personality and } \\
\text { behavior }\end{array}$ & 30 & $75 \%$ \\
\hline Factor 4 & $\begin{array}{l}\text { Competence and } \\
\text { classroom management }\end{array}$ & 29 & $72.5 \%$ \\
\hline Factor 5 & $\begin{array}{l}\text { Attitude and } \\
\text { commitment }\end{array}$ & 28 & $70 \%$ \\
\hline
\end{tabular}

From the analysis further distinct components are constructed within the identified factors. Each factor is explained with all the details of the underlying themes. The number of participants reporting the same perception is mentioned in the parenthesis next to the citation.

\section{Factor 1: Teachers' Instructional Styles and Teaching Methods}

The most salient factor constructed from students' report was regarding their English teachers' instructional styles, teaching approaches and methods which affected their motivation towards learning English. A total number of 32 $(80 \%)$ participants reported their perceptions under this theme. Two underlying distinct factors were identified within this factor: (i) Instructional style, and (ii) Teaching methods/approaches. Table 2 summarizes the data.

Table 2. Teachers' Instructional Styles and Teaching Methods (Factor 1)

\begin{tabular}{|c|c|}
\hline Instructional style & Teaching methods/approaches \\
\hline $\begin{array}{l}\text { - no guidance to improve English } \\
\text { language skills (listening, speaking, } \\
\text { writing, and reading) (28) } \\
\text { - no clear explanations of lessons (24) } \\
\text { - little/no pair or group work (24) } \\
\text { - no response to students' questions (22) } \\
\text { - encouraged to memorize } \\
\text { conversational dialogues from } \\
\text { commercial books (22) } \\
\text { - discouraged to write in own words } \\
\text { (21) }\end{array}$ & $\begin{array}{l}\text { - little/no interaction with students } \\
\text { (25) } \\
\text { - little/no classroom activity of oral } \\
\text { communication (24) } \\
\text { - teacher centered boring lectures } \\
\text { (20) } \\
\text { - no/little demonstration on board } \\
\text { (15) } \\
\text { - encouraged memorization of } \\
\text { grammar and vocabulary (14) } \\
\text { - too much emphasis on grammar } \\
\text { (14) }\end{array}$ \\
\hline
\end{tabular}


Quadir, Teaching Factors That Affect Students' Learning Motivation 303

\begin{tabular}{|l|l|}
\hline \multicolumn{1}{|c|}{ Instructional style } & Teaching methods/approaches \\
\hline - & lots of homework but no feedback \\
& $(21)$ \\
- & writing practices were based on \\
memorization (20) & \\
- & used only textbooks (20) \\
- no interesting or effective grammar & \\
practice (16) & \\
- no listening practice in classrooms & \\
(15) & \\
- no explanation of grammatical rules & \\
for students' comprehension (12) & \\
- no practice of vocabulary learning (9) & \\
\hline
\end{tabular}

\section{Factor 2: Private Tutoring}

The second dominant factor which affected students' learning motivation was the practice of private tutoring in English. A total number of 30 participants (75\%) reported that they had to seek help of private tutors as the classroom instructions were not useful enough. Therefore, institutional English teachers are directly and/or indirectly related to this source of demotivation. In some cases, institutional English teachers are also involved in afterschool private tutoring. This factor comprised two sub-categories: (i) Payment and unavoidability, and (ii) Private tutors' competence and management. Table 3 presents Factor 2.

\section{Table 3. Private Tutoring (Factor 2)}

\begin{tabular}{|c|c|}
\hline Payment and unavoidability & $\begin{array}{c}\text { Private tutors' competence and } \\
\text { management }\end{array}$ \\
\hline $\begin{array}{l}\text { - } \text { private tutoring was unavoidable for } \\
\text { English as classroom instructions were } \\
\text { useless (26) } \\
\text { - I was / parents were unhappy to pay } \\
\text { private tutors (25) } \\
\text { - classroom teachers encouraged to take } \\
\text { help of private tutors (23) } \\
\text { - private tutoring reduced interest to } \\
\text { study independently (23) }\end{array}$ & $\begin{array}{l}\text { - taught a large number of students at } \\
\text { a time (18) } \\
\text { - } \text { private tutor/s was/were not } \\
\text { competent enough }(18) \\
\text { - } \text { ineffective feedback (16) } \\
\text { - } \text { stressed only exam-oriented } \\
\text { practices (11) } \\
\text { - unorganized instructions and } \\
\text { guidance (10) }\end{array}$ \\
\hline
\end{tabular}


304 TEFLIN Journal, Volume 32, Number 2, July 2021

\begin{tabular}{|l|c|}
\hline \multicolumn{1}{|c|}{ Payment and unavoidability } & $\begin{array}{c}\text { Private tutors' competence and } \\
\text { management }\end{array}$ \\
\hline - $\begin{array}{l}\text { inability to pay private tutors was } \\
\text { frustrating (20) }\end{array}$ & \\
- time consuming but inevitable (17) & \\
\hline
\end{tabular}

\section{Factor 3: Teachers' Personality and Behavior}

Altogether 30 participants (75\%) shared their perceptions under the theme of English teachers' personality and behavior which affected their motivation to study English. This factor consists of two sub factors: (i) Teachers' personality and (ii) Behavior. Table 4 reports the summary.

Table 4. Teachers' Personality and Behavior (Factor 3)

\begin{tabular}{|l|l|}
\hline \multicolumn{1}{|c|}{ Personality } & \multicolumn{1}{c|}{ Behavior } \\
\hline - $\begin{array}{l}\text { impatient to explain difficult lessons } \\
\text { slowly (24) }\end{array}$ & - $\begin{array}{l}\text { critical and rude to students' errors } \\
(25)\end{array}$ \\
- not easygoing/cheerful (20) & - $\begin{array}{l}\text { humiliate students in class for minor } \\
\text { mistakes (24) }\end{array}$ \\
& $\begin{array}{l}\text { did not encourage to overcome } \\
\text { weaknesses (22) } \\
\text { nice to some good students in class } \\
\end{array}$ \\
\hline
\end{tabular}

\section{Factor 4: Teachers' Competence and Classroom Management}

Under this factor, 29 participants (72.5\%) shared their perceptions regarding their instructors' competence and classroom management skills which reduced their motivation towards learning English. Two underlying sub-factors were identified here: (i) Competence and (ii) Classroom management skills. Table 5 shows the results.

Table 5. Teachers' Competence and Classroom Management (Factor 4)

\begin{tabular}{|c|c|}
\hline Competence & Classroom management skills \\
\hline $\begin{array}{l}\text { - unclear and unorganized instructions } \\
\text { in class (15) } \\
\text { - unclear/strange pronunciation (15) } \\
\text { - incompetent in spoken English (13) }\end{array}$ & $\begin{array}{l}\text { - no/few activities appropriate for large } \\
\text { class size (21) } \\
\text { - did not involve all students in } \\
\text { classroom activities (14) }\end{array}$ \\
\hline
\end{tabular}


Quadir, Teaching Factors That Affect Students' Learning Motivation 305

\begin{tabular}{|l|l|}
\hline \multicolumn{1}{|c|}{ Competence } & \multicolumn{1}{c|}{ Classroom management skills } \\
\hline - taught in Bangla (L1) (11) & - $\begin{array}{l}\text { did not know the purpose/s of doing } \\
\text { the activities in classroom (12) }\end{array}$ \\
- lrrelevant explanations (11) & left incomplete instructions on \\
lessons (10) & $\begin{array}{l}\text { did not try to interact with students } \\
\text { sitting in the back (12) }\end{array}$ \\
\hline
\end{tabular}

\section{Factor 5: Teachers' Attitude and Commitment}

The final factor constructed from students' perceptions points to their instructors' commitment and attitude in classrooms. The two distinct sources of students' demotivation under this factor are English teachers' (i) Attitude, and (ii) Commitment. Of the total number of participants $28(70 \%)$ shared their perceptions under this factor. The incidents are listed in Table 6.

Table 6. Teachers' Attitude and Commitment (Factor 5)

\begin{tabular}{|l|l|}
\hline \multicolumn{1}{|c|}{ Attitude } & \multicolumn{1}{|c|}{ Commitment } \\
\hline - $\begin{array}{l}\text { guided only some good students in class } \\
\text { (18) }\end{array}$ & - $\begin{array}{l}\text { did not motivate students to } \\
\text { study English seriously (17) }\end{array}$ \\
- $\begin{array}{l}\text { did not listen to students' problems in } \\
\text { learning (16) }\end{array}$ & - $\begin{array}{l}\text { teachers themselves were not } \\
\text { motivated in classrooms (12) }\end{array}$ \\
- $\begin{array}{l}\text { expected students to perform satisfactorily } \\
\text { without prior instructions (16) }\end{array}$ & - $\begin{array}{l}\text { usually late to class (10) } \\
\text { - } \begin{array}{l}\text { neglected poorly performing students (11) } \\
\text { negular (9) }\end{array}\end{array}$ \\
\hline
\end{tabular}

\section{Contextually Feasible Remedial Measures}

Based on the teaching factors identified in the current study some contextually feasible remedial measures are discussed in the following.

\section{Teachers' Instructional Style and Teaching Method}

This factor comprises students' perceptions about English teachers' instructional styles, teaching methods and approaches which affected their motivation to study English. This finding is consistent with some research studies conducted in Asian contexts (Falout et al., 2009; Kikuchi, 2009; Quadir, 2017; Song \& Kim, 2017; Trang \& Baldauf, 2007). The reported incidents inform us of students' perceptions of their classroom instructions along with their 
expectations from classroom teaching. For effective pedagogy it is necessary to align instructional style and teaching method with students' interests and needs (Trang \& Baldauf, 2007).

This study reveals that HS students expect guidance to improve their English language skills from their classroom instructions. Therefore, familiarizing students with diverse language learning strategies to enhance language skills (e.g., listening, speaking, reading, writing, grammar, and vocabulary) is supposed to meet students' expectations. Oxford (1990) emphasized that L2 learning strategies "make learning easier, faster, more enjoyable, more self-directed, more effective and more transferable to new situations" (p. 8). Studies conducted in L2 contexts have revealed significant correlations between strategy use and L2 proficiency (Cohen, 1998). With some prerequisite preparations it is possible to provide students with orientation and training on a range of language learning strategies within classroom settings. The teachers' training programs need to provide substantial support to prepare English teachers to incorporate language learning strategy-oriented activities in classrooms.

Uninteresting and traditional teaching methods and approaches are some of the most detrimental factors that affect students' motivation towards learning English. These factors are listed as common complaints in many other EFL contexts (see Jung, 2011; Kikuchi, 2009; Trang \& Baldauf, 2007). Making teaching-learning activities interesting in language classrooms is a complex process. Teacher training programs need to emphasize on this significant pedagogical issue in an EFL context. To sustain students' attention and interest in English classrooms it is necessary to maintain variation in teaching-learning activities. To bring variation EFL instructors may plan and design classroom activities incorporating both receptive and productive language skills appropriate for their students' proficiency level. All the macro language skills (listening, speaking, reading, and writing) need to be alternatively and proportionately practiced in English classrooms. Incorporating pair works, group works (small or large groups) in language classrooms would potentially contribute to reduce monotony and boredom of conventional classroom atmosphere and would allow students to interact in the target language exploiting their linguistic capacity (Dörnyei, 2007). EFL teachers and teacher trainers also need to emphasize the practice of student-centric classroom activities relevant to learners' needs and interests. The positive outcomes of student-centered teaching 
approaches are widely appreciated in many L2 contexts (Dörnyei, 2007; Trang \& Baldauf, 2007).

Instructors' tendency to persuade students to memorize textual content, vocabulary and grammar of the target language causes demotivation towards learning English (see Quadir, 2017; Song \& Kim, 2017). Instructors of English language classrooms need to be aware of the fact that memorization is an ineffective practice for L2 learning. Effective learning requires comprehensive instructions and active practice of linguistic elements (e.g., phonological, lexical, syntactic, grammatical elements). Students need to be provided with adequate exposure, exercises, and practices in classrooms. Since grammar and vocabulary are integral parts in learning a foreign language, classroom instructions on these linguistic elements need to be interesting and engaging. The Internet is an enormous source of teaching-learning materials of English grammar and vocabulary for different proficiency levels. To facilitate classroom activities of grammar and vocabulary, English teachers need the provision of accessibility to those materials and short-term orientation programs on how to exploit those online resources. Adequate support of logistic facilities is a vital concern to ensure the effectiveness of using online resources for language pedagogy.

Effective feedback plays a powerful role to guide and motivate students towards learning activities (Kaboody, 2013). While giving feedback teachers need to carefully insert some inspirational elements which may promote EFL students to invest their efforts more enthusiastically. Furthermore, language teachers need to be aware of planning comprehensive and comprehensible instruction to ensure usefulness of institutional English classes. They also need to address students' questions and confusions to facilitate their learning process.

\section{Private Tutoring}

From the analysis of qualitative data, private tutoring appears to be the second potent source of students' disinterest to study English. This factor may be unique to the context of Bangladeshi education. Private tutoring is a common practice at most of the academic levels in Bangladesh (Hamid et al., 2017). Private tutoring consumes huge family resources in this low-economy country. It is apparent from students' report that they are unhappy to buy private tuition spending the amount of money. Though the institutional English teachers may or may not be always directly involved in private tutoring, uselessness of classroom 
instructions forces both students and parents towards buying extra private tuition (Hamid et al., 2017).

In Bangladesh, there is government legislation against private tutoring; however, implementation of all those restrictions will be realistic only when teachers would be sanctioned reasonable amount of salary. Teachers of some institutions receive inadequate amount of monthly salary amid the high price of essential commodities (Quadir, 2017). It is also necessary to upgrade job facilities of institutional English teachers to attract qualified and competent candidates and to enhance quality of classroom teaching. Furthermore, English teachers need to be aware of the fact that effectiveness of classroom instructions will practically reduce the needs for private tutoring.

\section{Teachers' Personality and Behavior}

Teachers' disagreeable personality and unbecoming behavior are found to be strong sources of students' demotivation in many EFL contexts (see Kikuchi, 2009; Quadir, 2017; Trang \& Baldauf, 2007). Many language teachers are unaware of their students' affective factors, and the powerful effects of those negative experiences in creating long term disinterest towards the subject (Trang $\&$ Baldauf, 2007). The psychological climate of a learning context is hugely important (Dörnyei, 2007) as L2 learners learn better in a fear free environment where they are not afraid of losing face in front of their peers (Nakata, 2006). Based on the students' reports the following recommendations are proposed.

English teachers need to be aware of creating and maintaining an anxiety free classroom atmosphere where all the students, of all proficiency levels, feel enthusiastic to participate in classroom activities. Teachers' positive behavior with students, supportive and inspiring comments can contribute to bring positive learning outcomes in foreign language classrooms (Wubbels et al., 2016). Language instructors need to remain aware of the fact that mistakes and errors are natural parts in L2 learning. Weak students' poor performance needs to be handled with patience and compassion. Language learners' affective factors need to be significantly incorporated in teachers' training programs and institutional policy. A provision of counseling within institutional setting may also be supportive to remedy emotionally affected learners. 
Quadir, Teaching Factors That Affect Students' Learning Motivation 309

\section{Teachers' Competence and Classroom Management}

This study detects that teachers' incompetence and poor classroom management skills adversely affect students' motivation. It is a commonly accepted fact that competent teachers succeed in enhancing students' competence (Trang \& Baldauf, 2007). Therefore, the following initiatives may be suggested to ameliorate the condition.

To effectively engage EFL students in classroom activities, it is necessary to plan pragmatically relevant lessons for classroom practices (Kaboody, 2013). Large class size is a common challenge in the context of Bangladesh. Planning, incorporating and conducting pair works and group works would be helpful for involving a large number of students in classroom activities at a time. English teachers' encouragement and guidance to engage in outdoor language learning activities would inspire students to carry out and involve in learning activities outside of classrooms.

\section{Teachers' Attitude and Commitment}

Instructors' attitude and commitments towards teaching are essential qualities for effective classroom pedagogy. Education psychology asserts that teacher's commitment and enthusiasm get contaminated among students (Dörnyei \& Ushioda, 2011), and therefore, committed teachers contribute to promoting students' motivation in EFL classrooms. The following suggestions are proposed regarding English teachers' attitude and commitment.

In EFL contexts it is important to create and culture democratic classroom environment to engage each student in learning activities. Instructors' interactions with only the proficient students in class promotes a sense of negligence among the deprived ones. Classroom teachers' negligence and the resulted feeling of deprivation may create acute disinterest towards the subject and learning activities as well (Trang \& Baldauf, 2007). Teachers need to remain careful about fair distribution of classroom activities among all the attendees with proportionate involvement. In large classrooms it may be necessary for teachers to keep record of students' participations on the student-lists to manage impartial distribution of classroom activities. 


\section{CONCLUSIONS}

There has been little academic attention to the dynamic nature of studentteacher interactions and the resulted outcomes in the EFL classrooms in the context of Bangladesh. This study has tried to explore students' perceptions to identify the teaching factors that adversely affect their motivation to study English as a school subject. The qualitative analysis of students' perceptions of teaching practices presents a collective picture of HS level English language classrooms in Bangladesh. The identified factors of this study point to a range of cultural, educational, social and economic factors and their interactions in this context.

Implementation of effective teaching practices is a demanding and complex process, and to a large extent dependent on teachers' capacity (Fullan, 2007). In this EFL context of Bangladesh, the culture of top-down policy initiatives of curriculum reformation has invariably ignored the necessity of building-up teachers' capacity in a large scale. Teachers' professional qualities are largely dependent on teacher-training process, recruitment policy, provision of professional facilities, logistic support and so on and so forth. It is important to note that, English language teachers in Bangladesh have never been provided with adequate training facilities, pedagogical guidance, economic support, and teaching materials to prepare themselves for quality instructions. Furthermore, English education in Bangladesh has never been supported by any contextually feasible policy framework (Rahman \& Pandian, 2018) which would contribute to upgrading and enhancing English teachers' professional skills and effectiveness of English pedagogy.

The principle main objectives of this research were to explore EFL students' perceptions of their classroom teaching in order to identify the teaching factors that adversely affect their motivation to study English, and to propose some contextually feasible remedial measures addressing the identified factors of the current study. The findings of the study would be insightful for English language teachers to reflect on students' needs and expectations in their classroom teaching preparations. Furthermore, they would be informative for the stakeholders of English education (e.g., education policymakers, curriculum developers, teacher trainers, and especially English teachers), particularly in Bangladeshi context. This study implicates future reformation policy of English teachers' professional development, English language education, and teachers' training programs in the context of Bangladesh. Though this research 
investigation is limited to the self-report interview data of a convenience sample, and therefore may present a partial picture of the whole scenario, it provides an opportunity to look into the classroom practices from students' perspectives. Further research might aim to implement the proposed remedial measures through action research, teacher training or professional development programs to contribute to increasing English teacher competence and their professional development.

\section{REFERENCES}

Alam, F. (2018). Revisioning English studies in Bangladesh in the age of globalization and ELT. In R. Chowdhury, M. Sarker, F. Mojumder \& M. Rashid (Eds.), Engaging in education research: Revisiting policy and practice in Bangladesh (pp. 241-262). Springer Nature. https://doi.org/10.1007/978-981-13-0708-9_13

Alavinia, P. \& Sehat, R. (2012).A probe into the main demotivating factors among Iranian EFL learners. English Language Teaching, 5(6), 9-35. https://doi.org/10.5539/elt.v5n6p9

Ali, M., \& Walker, A. L. (2014). "Bogged down” ELT in Bangladesh: Problems and policy.' English Today, 30(2), 33-38. https://doi.org/10.1017/S0266078414000108

Benson, P. (2005). (Auto)biography and learner diversity. In P. Benson \& D. Nunan (Eds.), Learners' stories: Difference and diversity in language learning (pp. 4-21). Cambridge University Press.

Cohen, A. D. (1998). Strategies in learning and using a second language. Longman.

Creswell, J. W., \& Poth, C. N. (2017). Qualitative inquiry and research design: Choosing among five approaches ( $4^{\text {th }}$ ed.). Sage.

Dörnyei, Z. (2007) Creating a motivating classroom environment. In: J. Cummins \& C. Davison (Eds.), International handbook of English language teaching (pp. 719-731). Springer. https://doi.org/10.1007/978-0387-46301-8_47

Dörnyei, Z., \& Ushioda, E. (2011). Teaching and researching motivation ( $2^{\text {nd }}$ ed.). Routledge.

Erlign, E. J., Seargeant, P. \& Solly, M. (2014). English in rural Bangladesh: How is language education perceived as a source for development in rural 
312 TEFLIN Journal, Volume 32, Number 2, July 2021

communities? English Today, 30(4), 15-21. https://doi.org/10.1017/S0266078414000352

Falout, J., Elwood, J. \& Hood, M. (2009). Demotivation: Affective states and learning outcomes. System, 37(3), 403-417. https://doi.org/10.1016/j.system.2009.03.004

Fullan, M. (2007). The new meaning of educational change ( $4^{\text {th }}$ ed.). Routledge. Hamid, M. O., \& Baldauf Jr, R. B. (2011). English and socioeconomic disadvantage: Learner voices from rural Bangladesh. Language Learning Journal, 39(2), 201-217. https://doi.org/10.1080/09571736.2011.573687

Hamid, M, O, \& Honan, E. (2012). Communicative English in the primary classroom: Implementations for English-in-education policy and practice in Bangladesh. Language, Culture and Curriculum, 25(2), 139-156. https://doi.org/10.1080/07908318.2012.678854

Hamid, M. O., Khan, A., \& Islam, M. (2017). The spread of private tutoring in English in developing societies: Exploring students' perceptions. Discourse: Studies in the Cultural Politics of Education, 39(6), 868-886. https://doi.org/10.1080/01596306.2017.1308314

Heidari, A., \& Oghli, H. (2015). De-motivational factors of speaking English: A case of Iranian high school students. International Journal of Language Learning and Applied Linguistics World, 9(3), 115-122.

Islam, A. S. M. (2015). Language policy and practice in secondary school contexts in Bangladesh: Challenges to the implication of language in education policy [Doctoral dissertation, Aalborg University, Denmark). https://doi.org/10.5278/vbn.phd.hum.00006

Jung, S. K. (2011). Demotivating and remotivating factors in learning English: A case low level college students. English Teaching, 66(2), 47-72. http://dx.doi.org/10.15858/engtea.66.2.201106.47

Kaboody, M. (2013). Second language motivation: The role of teachers in learners' motivation. Journal of Academic and Applied Studies, 3(4), 45-54.

Karim, A., Mohamed, A. R., Ismail, S. A. M. M., \& Rahman, M. M. (2018). Organized hypothesis in EFL teacher training programs. International Journal of Instruction, 11(2), 437-450. http://www.eiji.net/dosyalar/iji_2018_2_30.pdf

Kikuchi, K. (2009). Listening to our learners' voice: What demotivates Japanese high school students? Language Teaching Research, 13(4), 453-471. https://doi.org/10.1177/1362168809341520 
Quadir, Teaching Factors That Affect Students' Learning Motivation 313

Kim, T. -Y., \& Lee, J. -Y. (2013). Korean students' English learning motivation and demotivation through biographic essays: Retrospective reconstruction. Korean Journal of Applied Linguistics, 29(1), 37-68. http://dx.doi.org/10.17154/kjal.2013.03.29.1.37

Kim, T.-Y., Kim, Y., \& Kim, J.-Y. (2018). A qualitative inquiry on EFL learning demotivation and resilience: A study of primary and secondary EFL students in South Korea. Asia Pacific Education Research, 27(1), 55-64. https://doi.org/10.1007/s40299-017-0365-y

Lamb, M. (2017). The motivational dimension of language teaching. Language Teaching, 50(3), 301-346. https://doi.org/10.1017/S0261444817000088

Miles, M. B., \& Huberman, A. M. (1994). Qualitative data analysis: An expanded sourcebook. Sage.

Nakata, Y. (2006). Motivation and experience in foreign language learning. Peter Lang Publishing.

National Curriculum and Textbook Board (NCTB). (2003). Project Performance (PP) for English Language Teaching Improvement Project (ELTIP): Phase2. NCTB.

Oxford, R. L. (1990). Language learning strategies: What every teacher should know. Harper \& Row.

Quadir, M. (2017). Let us listen to our students: An analysis of demotivation to study English in Bangladesh. The English Teacher, 46(3), 128-141. https://journals.melta.org.my/TET/downloads/tet46_03_03.pdf

Rahman, M. M., Johan, M., Selim, S. M. M., Singh, M. K. M., \& Shahed, F. H. (2019). Teachers' beliefs and practices of implementing secondary English curriculum reform in Bangladesh: A phonological study. The Journal of Asia TEFL, 16(2), 591-607. http://dx.doi.org/10.18823/asiatefl.2019.16.2.10.591

Rahman, M. M. \& Pandian, A. (2018). A critical investigation of English language teaching in Bangladesh: Unfulfilled expectations after two decades of Communicative Language Teaching. English Today, 35(3). 43 49. https://doi.org/10.1017/S026607841700061X

Rahman, M. M., Pandian, A., \& Kaur, M. (2018). Factors affecting teachers' implementation of communicative language teaching curriculum in secondary schools in Bangladesh. The Qualitative Report, 23(5), 11041126. https://doi.org/10.46743/2160-3715/2018.3220 
Sakai, H., \& Kikuchi, K. (2009). An analysis of demotivators in the ELT classroom. System, 37(1), 57-69. https://doi.org/10.1016/j.system.2008.09.005

Song, B., \& Kim, T-Y. (2017). The dynamics of demotivation and remotivation among Korean high school EFL students. System, 65, 90-103. https://doi.org/10.1016/j.system.2016.12.010

Stockwell, R. (2015). An exploratory study investigating the factors which explain Abu Dhabi Education Council's (ADEC) English curriculum choice in grade 10/11 public high schools and the challenges its implementation poses for teachers [Doctoral dissertation, University of Exeter, United Kingdom]. https://ore.exeter.ac.uk/repository/handle/10871/17338

Trang, T. \& Baldauf, R. (2007). Demotivation: Understanding resistance to English language learning - The case of Vietnamese students. The Journal of Asia TEFL, 4(1), 79-105.

Wubbels, T., Brekelmans, M., Mainhard, T., Brok, P. J., \& Tartwijk, J. (2016). Teacher student relationships and student achievement. In K. R. Wentzel. \& G. B. Ramani (Eds.), Handbook of social influences in school contexts: Social-emotional, motivation and cognitive outcomes (pp. 127-142). Routledge. 
Quadir, Teaching Factors That Affect Students' Learning Motivation 315

\section{Appendix}

\section{Interview guide}

1. How is your study going on?

2. Did you enjoy learning English as a high school subject?

3. From which area (district/city/town/ village) have you completed your high school education?

4. Please share your perceptions and feelings on the following points regarding your higher secondary (HS) level (grade 11 \& 12) English teachers' teaching practices which affected your motivation to study English

- instructional skills

- teaching methods

- attitude

- behavior

- classroom management skills

- commitment to teaching

- private tutoring

5. Is there any important point left what you want to share here? 